\title{
The study of the features of the working process of the engine using gasoline-hydrogen fuel
}

\author{
Ismatov J.F. ${ }^{1}$, Ashirov V.R. ${ }^{2}$ \\ ${ }^{1}$ Tashkent Institute for the Design, Construction and Operation of Highway, Uzbekistan \\ ${ }^{2}$ Tashkent State Polytechnic Institute after name Islam Karimov, Uzbekistan \\ Email: ismatovjj@umail.uz
}

\begin{abstract}
In this paper, we analyze the obtained data on the supply of hydrogen to internal combustion engines as a supplement to binzen.On this case, The study of the features of the working process of the engine using gasoline-hydrogen fuel were stated. Conclusions were provided in the further research points of the relevant authors.
\end{abstract}

Keywords: The study, features, working process, engine, gasoline, hydrogen fuel.

\section{INTRODUCTION}

The program provided for the study of the features of the working process and the removal of the main characteristics of a serial engine and engine when using the addition of hydrogen to gasoline.

One of the main factors affecting the course of the working process, and as a result on the effective and economic performance of the engine, is the angle of advance of the fuel supply (injection). If the lead angle is too large, the fuel injection starts at a relatively low pressure and low temperature, which leads to an increase in the ignition delay period, the accumulation of a large dose of evaporated fuel to the beginning of the rapid combustion phase and an excessively hard course of the combustion process.

The purpose of the tests: the study and determination of the operating conditions of a Cobalt hydrogen car as an additive to gasoline and the determination of fuel consumption for a route of $100 \mathrm{~km}$.

The object of the test is a Cobalt passenger car running on gasoline and hydrogen as additives on the route of $100 \mathrm{~km}$. During the test of a car, Cobalt running on gasoline and with the addition of hydrogen, its loading corresponded to the actual operating conditions.

To obtain statistics on fuel consumption of a Cobalt car gasoline and hydrogen gasoline additive, control measurements of fuel consumption are carried out. Before testing, a check is made of the technical condition of the vehicle.

The test procedure was carried out on the basis of O'zDst 1.6: 2003 GSS Uz, regulatory documents, general requirements for the construction, presentation, design, content and designation, O’zDst 8.016: 2002. Methodology for performing measurements, MI-2377-98. Development and certification of measurement procedures. - M.: VNIIMS, 1998 .-- 31 p. [1,2,3,4].

Tests are carried out on cars with serviceable, sealed and verified speedometers. Driving cars should be carried out in the same way as in ordinary operation. During the tests, a survey of operating conditions is carried out, a survey protocol is compiled, which contains the data necessary for the further calculation of the standard coefficients:

$>$ total mileage along the route;

$>$ the number of forced stops on the route;

$>$ the number of regulated and non-regulated intersections on the route;

$>$ number of turns;

$>$ the number of ascents and descents;

$>$ speed limits;

The driver, together with the inspector conducting the inspection, must check before leaving for damage, oil leakage, coolant and shock absorber, check the engine refueling with coolant and oil recommended by 
the manufacturer, refuel the full tank to the neck, and also make all other necessary daily maintenance work. In the process of work, they are also obliged to carefully conduct a control inspection and make sure that there are no damage listed above.

The determination of the amount of gasoline consumed is established by the measurement results of the following quantities:

- refuel a full tank to the neck and mark the mark before measuring;

- at the end of the test by adding gasoline to the gas tank to the mark on the neck and the amount of fuel consumed is measured;

- $\quad$ ambient temperature;

- distance traveled during the test;

- test time.

The measuring instruments used must satisfy the requirements given in table 1, which have passed state verification in the prescribed manner. The measuring instrument must be installed and secured in a place where its scale is easily visible to the tester. The sensor for measuring the ambient temperature must be protected from direct sunlight and must not touch hard surfaces.

Table 1. List of measurements

\begin{tabular}{|c|c|c|c|c|c|c|}
\hline \multirow{2}{*}{ № } & \multirow[t]{2}{*}{$\begin{array}{l}\text { Name of the } \\
\text { measured value }\end{array}$} & \multirow{2}{*}{$\begin{array}{c}\text { Unit of } \\
\text { measuremen } \\
\mathrm{t}\end{array}$} & \multirow{2}{*}{ Meaning } & \multicolumn{3}{|c|}{ Recommended equipments } \\
\hline & & & & name & $\begin{array}{l}\text { Accuracy } \\
\text { class }\end{array}$ & $\begin{array}{l}\text { Measuring } \\
\text { range }\end{array}$ \\
\hline 3 & $\begin{array}{l}\text { Gas (ambient air) } \\
\text { temperature }\end{array}$ & ${ }^{0} \mathrm{C}$ & $\mathrm{t}_{2}$ & $\begin{array}{c}\text { Glass } \\
\text { meteorological } \\
\text { thermometer } \\
\text { ГОСТ } 112\end{array}$ & 1.0 & $-10-0+100$ \\
\hline 4 & Test time & сек & $\mathrm{T}$ & $\begin{array}{c}\text { Stopwatch } \\
\text { ГОСТ } 5072\end{array}$ & 0.5 & - \\
\hline 5 & $\begin{array}{l}\text { Vehicle mileage } \\
\text { during testing }\end{array}$ & КМ & $\mathrm{S}$ & $\begin{array}{c}\text { Speedometer } \\
\text { ГОСТ } 12936 \\
\text { (СТ СЭВ } \\
48657)\end{array}$ & 0.5 & - \\
\hline
\end{tabular}

Note: Tests should be carried out at: wind speed not more than $3 \mathrm{~m} / \mathrm{s}$, no precipitation, air temperature from -5 to $+250 \mathrm{C}$, atmospheric pressure from 730 to $760 \mathrm{~mm} \mathrm{Hg}$, atmospheric humidity not higher than $90 \%$.

The method for measuring the amount of gasoline consumed during testing is to determine the change at the end of the test by adding gasoline to the mark.

The amount of gasoline consumed during testing is determined by the formula

$$
\mathrm{Q}_{\bar{\sigma}}=\mathrm{Q}_{\Pi}-\mathrm{Q}_{\text {пд}}, \text { л }
$$

Where, $\quad \mathrm{Q}_{\tilde{\sigma}}-$ fuel consumed, л

$$
\begin{aligned}
& \mathrm{Q}_{\Pi} \text { - the volume of a full tank of fuel to the neck, л } \\
& \mathrm{Q}_{\text {пд }} \text { - residual fuel tank during test, л }
\end{aligned}
$$

Example: during testing of a Cobalt car with gasoline consumed fuel:

$\mathrm{Q}_{6}=\mathrm{Q}_{\Pi}-\mathrm{Q}_{\text {пд }}=46 л-38,7 л=7,3$ liter;

during tests of the Cobalt car with the addition of hydrogen to gasoline spent fuel: $\mathrm{Q}_{6}=\mathrm{Q}_{\pi^{-}}$ $\mathrm{Q}_{\text {пд }}=46 л-40,3 л=5,7 л$;

Defining $Q_{\sigma}$, knowing the mileage $S$ car and useful work done $W$ You can calculate mileage or vehicle fuel consumption:

$$
\mathrm{Q}_{\mathrm{n}}=100 \cdot Q_{\sigma} / S, \quad M^{3} / 100 \kappa M
$$




$$
Q_{m}=Q_{\sigma} / W, \quad M^{3} / m \kappa M
$$

where $Q_{\sigma}-$ gas consumption, л;

$S$ - car mileage, $\kappa m$;

$W$ - useful work done, $m \cdot \kappa M$.

Table 2 shows the results of measurements of fuel consumption along the route $100 \mathrm{~km}$ "Tashkent - Chirchik - Tashkent" and within the city of Chirchik Cobalt.

Таблица 2.

\begin{tabular}{|c|c|c|c|c|c|c|c|}
\hline \multirow[b]{2}{*}{ Fuel } & \multirow[b]{2}{*}{ № rides } & \multirow{2}{*}{$\begin{array}{l}\text { Ride } \\
\text { length } \\
\text {, } \\
\mathrm{km}\end{array}$} & \multicolumn{2}{|c|}{$\begin{array}{l}\text { Fuel level indication, } \\
\text { л }\end{array}$} & \multirow{2}{*}{$\begin{array}{l}\text { Direction of } \\
\text { travel }\end{array}$} & \multirow{2}{*}{$\begin{array}{c}\text { Actual fuel } \\
\text { consumption } \\
\text { per mileage, } \\
1 / 100 \mathrm{~km}^{*}\end{array}$} & \multirow{2}{*}{$\begin{array}{l}\text { Actual fuel } \\
\text { consumption } \\
\text { per mileage } \\
1 / 100 \mathrm{~km}^{* *}\end{array}$} \\
\hline & & & $\begin{array}{l}\text { before the } \\
\text { test }\end{array}$ & $\begin{array}{l}\text { B end of } \\
\text { trial }\end{array}$ & & & \\
\hline 1 & 2 & 3 & 4 & 5 & 6 & 7 & 8 \\
\hline \multirow{3}{*}{ 完 } & 1 & 100 & 46 & 38,81 & \multirow{6}{*}{ 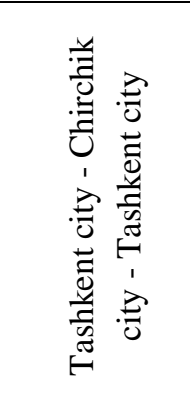 } & - & 7,29 \\
\hline & 2 & 100 & 46 & 38,69 & & - & 7,31 \\
\hline & $\begin{array}{c}\text { Average } \\
\text { index }\end{array}$ & & & & & - & 7,3 \\
\hline \multirow{3}{*}{ 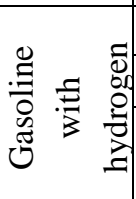 } & 4 & 100 & 46 & 40,32 & & - & 5,68 \\
\hline & 5 & 100 & 46 & 40,28 & & - & 5,72 \\
\hline & $\begin{array}{c}\text { Average } \\
\text { index }\end{array}$ & & & & & - & 5,7 \\
\hline
\end{tabular}

Note:

* - fuel consumption rate using a heater.

** - fuel consumption rate without using a heater.

Based on the initial data obtained during the control measurements of fuel consumption, a generalized table is compiled, in which the following data is entered:

\# state number of the tested car, its brand (model);

\# total mileage according to the speedometer in kilometers;

\# actual fuel consumption in liters;

* the value of the calculated actual fuel consumption in liters per 100 kilometers.

The test processing results for the route "Tashkent - Chirchik - Tashkent" for the Cobalt car are shown in table 3 .

Table 3.

\begin{tabular}{|l|c|c|c|}
\hline \multirow{2}{*}{ Fuel } & Average consumption & $\begin{array}{c}\text { Deviation from the } \\
\text { average value } x_{i}-\bar{x}\end{array}$ & $\left(x_{i}-\bar{x}\right)^{2}$ \\
\hline \multirow{2}{*}{ Petrol } & 7,29 & $-0,1$ & 0,01 \\
\cline { 2 - 4 } & 7,31 & 0,1 & 0,01 \\
\hline $\begin{array}{l}\text { Gasoline with } \\
\text { hydrogen }\end{array}$ & 5,68 & $-0,2$ & 0,04 \\
\cline { 2 - 4 } & 5,72 & 0,2 & 0,04 \\
\hline
\end{tabular}

With petrol

$\bar{x}=14,4: 2=7,21 / 100 \mathrm{~km}$

Gasoline with hydrogen $\bar{x}=11,4: 2=5,71 / 100 \mathrm{~km}$

Standard deviation: 
With petrol $\quad \sigma=\sqrt{\frac{\sum_{i=1}^{n}\left(x_{i}-\bar{x}\right)^{2}}{n}}=\sqrt{\frac{0,02}{2}}=\sqrt{0,01}=0,11 / 100 \mathrm{~km}$

Gasoline with hydrogen $\sigma=\sqrt{\frac{\sum_{i=1}^{n}\left(x_{i}-\bar{x}\right)^{2}}{n}}=\sqrt{\frac{0,08}{2}}=\sqrt{0,04}=0,21 / 100 \mathrm{~km}$

Dispersion:

$$
\sigma^{2}=\frac{\sum_{i=1}^{n}\left(x_{i}-\bar{x}\right)^{2}}{n}=\frac{0,08}{2}=0,04
$$

The root-mean-square error of the measurement result or the standard of an individual measurement is determined:

$$
S=\sqrt{\frac{\sum_{i=1}^{n}\left(x_{i}-\bar{x}\right)^{2}}{n-1}}=\sqrt{\frac{0,08}{1}}=\sqrt{0,08}=0,282
$$

The root-mean-square error of the summary measurement result or the arithmetic mean standard is calculated by the formula:

$$
S_{\bar{x}}=\frac{S}{\sqrt{n}}=\frac{0,282}{\sqrt{2}}=\frac{0,282}{1,41}=0,2 .
$$

Accuracy rate:

$$
\frac{S_{\bar{x}}}{\bar{x}} * 100 \%=\frac{0,2}{7,2} * 100=0,27 \% .
$$

Therefore: - confidence boundary:

With gasoline

$I_{H I}=7,2-0,01=7,19$ л $/ 100 \mathrm{kM}$

Gasoline with hydrogen:

$$
I_{H 2}=5,7-0,04=5,661 / 100 \mathrm{~km}
$$

\section{CONCLUSION}

The operational standard fuel consumption per mileage of $100 \mathrm{~km}$ for a passenger car is Cobalt with gasoline $7.31 / 100 \mathrm{~km}$ and hydrogen gasoline additives $5.71 / 100 \mathrm{~km}$. Fuel economy is up to $20 \%$. If one car drives an average of $200 \mathrm{~km}$ per day, then saving gasoline per $100 \mathrm{~km}-1.6$ liters, $200 \mathrm{~km}-3.2$ liters. Now one liter of gasoline costs 4,500 soums (\$ 0.4774) (the dollar exchange rate for the Central Bank of the Republic of Uzbekistan is September 24, 2019, \$ $1=9424.54$ soums). Then we get the saving of one car: per day $3.2 * 4500=14,400$ sum $(3.2 * 0.4774=\$ 1.5279)$, per month $25 * 14400=360000$ sum $(25 * 1.5279=38,1975 \$)$ and for the year $12 * 360,000=4,320,000$ sum $(12 * 38.1975=\$ 458.37)$.

\section{REFERENCES}

1. Test Methodology O'zDst 1.6: 2003 GSS Uz.

2. Regulatory documents, general requirements for the construction, presentation, design, content and designation, O'zDst 8.016: 2002.

3. Methodology for performing measurements, MI-2377-98.

4. Development and certification of measurement procedures. - M.: VNIIMS, 1998 .- $31 \mathrm{p}$. 